\title{
Public libraries in South Africa - agents or victims of educational change?
}

\author{
Genevieve Hart ${ }^{\prime}$ \\ Department of Library \& Information Science, University of the Western Cape \\ Private Bag X17, Bellville 7535 \\ ghart@uwc.ac.za
}

Received: $19^{\text {th }}$ September 2003

Revised: $13^{\text {th }}$ January 2004

\begin{abstract}
The paper explores the impact of educational change in South Africa on public libraries. It surveys the recent literature to conclude that the position of school libraries is precarious and that public librarians feel victimised by the new curriculum. This represents a puzzling contradiction, as librarians' expectations were that the ethos and methodologies of the new curriculum, Curriculum 2005 (C2005), would provide a more favourable climate. The curriculum has indeed brought increased use of public libraries by school learners, yet there has been little recognition in official quarters of the educational role of public libraries. It is suggested that, if librarians are to gain a better footing in curriculum planning, they need to engage with educationists as to the role libraries play in resource-based learning. They will need to provide documented evidence by means of research studies. As an example of such a study, the paper describes the author's study of school learners' use of two public libraries in a disadvantaged community in Cape Town. The libraries were found to be playing a crucial role in the learning programme of the learners. However, it is suggested that the two libraries need to design more systematic structured programmes if the needs of school learners for information literacy education are to be met. This might require explicit endorsement of their educational role by their own governance structures and the provincial Education Department.
\end{abstract}

\section{Introduction}

This paper explores the impact of educational transformation in South Africa on public libraries. It suggests that the pressures of educational change might lead to new library models - more appropriate to the needs of their communities than the services inherited from the Western tradition. The paper argues that the changes in ethos and teaching styles since 1994 offer the library profession an opportunity to take on a more prominent role in education - and therefore indeed in social development. The new school curriculum, with its acceptance of the need for information literacy and its shift to resource-based learning, has given librarians the room to become agents of change. The word 'agent' implies a pro-active leadership role - in contrast to the more passive supportive role usually assumed appropriate for the library profession within educational circles. The library profession perhaps has a crucial choice to make in the next few years. It can take up the opportunity for enhanced influence that educational change presents, or it can continue to wait in the wings - hoping for its potential contribution to be noticed

If public librarians are to become agents of change, then they will need to examine their credibility among educationists. This will depend on evidence that they do indeed contribute to the learning programme. More explicit recognition of its significant role in South Africa's new curriculum might provide the library profession with a stronger footing in educational decision-making and planning. The paper therefore reports on some examples of recent research that provide such evidence, including the author's own study conducted in October 2002.

This study set out to investigate school learners' use of two public libraries in a rapidly growing township on the outskirts of Cape Town. Over 800 interviews of school learners were conducted in an attempt to find out how their reading and information needs are being met. The central finding is that the public libraries are playing a crucial role in the teaching and learning within the schools. The vast majority of the respondents were coming to the library to do a 'project' and very few were able to mention any other information source apart from the public library. However, observation within the libraries and follow-up interviews with educators and library staff reveal that much work remains to be done to implement effective information literacy education.

\section{Educational change}

It is a truism that since 1994 South Africa has undergone a process of educational transformation. Our new curriculum, Curriculum 2005 (C2005) - implemented from 1997 onwards - is evidence of new ways of thinking about education and learning. These changes, of course, come from the need to construct a new integrated system from our fragmented and unequal apartheid education systems. But they also represent a response to global pressures. Internationally, there is recognition that the so-called information or knowledge society demands lifelong learners, for example. In his recent exploration of the interconnecting systems of society, Fritjof Capra (2003: 125) points out that, in an economy where

I. Genevieve Hart is a Senior Lecturer, Department of Library and Information Science, University of Western Cape, South Africa. 
'information processing innovation and knowledge creation are the main sources of productivity', employees able to educate themselves are prized. He defines self-educators as 'people who can access higher levels of education through their capacity to process information and to create knowledge' (p. 125). In the past few decades, throughout the world education systems have been shaken up and 're-formed' with the aim of producing school leavers able to solve problems and think independently (Fullan, 1991; Marsh \& Morris, 199I). Table I below summarises the shifts in classroom styles that are described across the literature of educational change (for example Brown, 1988; Fullan, 1991; Marsh \& Morris, |991).

Table I Educational change towards constructivism

\begin{tabular}{ll}
\hline Traditional classroom style & Constructivist classroom \\
\hline Teacher instructor & Teacher facilitator \\
Teaching isolated & Team teaching \\
Teacher autonomy & Cooperative activity \\
Group instruction & Individual instruction \\
Textbook reliance & Variety of resources \\
Self-contained classrooms & Learning as active discovery \\
& Learning as problem based \\
\hline
\end{tabular}

The moves towards constructivist approaches surely resonate with librarians. Librarians have indeed been quick to recognise the implications of these changes for their work. Breivik and Senn (1998: I -34), for example, analyse the educational reform movements of the 1980s in the United States in terms of the concept of 'resource-based learning' and the information literacy it demands. A glance at the literature of school and academic librarianship over the years, both in South Africa and internationally, soon reveals a thread of argument that links prevailing teaching ethos and styles to the success of the library (for example Brown, 1988; Stadler, 199I; Diepraam \& Bester, 1993; Asselin, 200 I; Ekhaml, 200I).

The outcomes-based approaches of South Africa's Curriculum 2005 (C2005) reflect international trends. It claims to have moved away from rote learning and memorisation. The 200I Revised National Curriculum Statement (Department of Education, 2002) lists the following attributes of the learner which reflect, it is claimed, the values and ethos of our constitution. The learner:

- has the linguistic skills needed for multi-lingual \& multicultural South Africa

- is curious and ready for scientific \& artistic discovery

- can adapt to an ever-changing environment

- has a problem-solving bent of mind

- can gather, analyse, organise, evaluate \& communicate information

- is able to take decisions in a complex technological society

- is equipped for the social, political \& economic demands of South Africa in our local and global context.

These attributes are echoed in the specific outcomes spelled out for each Learning Area of the new curriculum - as shown by Zinn (2002).

The fifth attribute in the above list is of specific interest to librarians as it gives them a foothold in the curriculum. In recent years, the library profession has identified information literacy as central to its social mission. Information literacy refers to the complement of skills that enable citizens to recognise a need for information, find information efficiently, analyse it and assess it critically, use it to meet the identified need and to solve problems. In addition, as Zinn (2002: 9) points out, all the other attributes in the above list overlap with information literacy. Libraries contribute directly to all of them.

The assessment methods and pedagogies of South Africa's new curriculum reflect its ethos. Portfolios of work and projects are used to assess learning - not only examinations. Analysis of the documentation shows teaching and learning to be 'resource-based' (Lombo, 2002: 4). Traditionally classrooms in South Africa and throughout the rest of the world have been full of chalk and talk. The teacher is 'the expert' who hands out knowledge with the aid perhaps of a textbook and notes. Shifts to constructivist approaches which see learning in terms of active discovery, problem-solving and knowledge construction should provide a more favourable climate for libraries which are the sites where much of this kind of independent learning takes place. This at least is the assumption of many librarians. Whether their understanding is shared by educationists is a thorny question.

Evidence of gaps in thinking between librarianship and educationists lies in the review and revision of Curriculum 2005 from 2000 onwards (Department of Education, 2000, 2002), which provided an opportunity for librarians to put their case. The review came after a series of reports on the failure of the curriculum, especially in the disadvantaged sector of schooling. Taylor and Vinjevold's influential survey of research in problems with C2005 came out in support of better 
availability of textbooks and stationery - arguing that they are what will most effectively and economically 'develop learners' conceptual knowledge structures' (p. 184). Indeed, the authors warn that 'learning materials that are not structured into a comprehensive learning programme are severely limited' (p. 182). The final report of the C2005 Review Committee states that 'well-resourced' schools are coping well with the new curriculum but there is no mention of libraries (Department of Education, 2000). Librarians perhaps would assume the existence of functioning libraries in these 'well-resourced' schools. However, the absence of any mention of libraries in the final Revision of C2005 (Department of Education, 2002), even after two representations to the Review Committee by LIASA's School Libraries and Youth Services Interest Group (Library \& Information Association of South Africa, 2000), indicates that educationists do not share this assumption. Perhaps librarians need to move away from the rather vague statements that 'resource-based learning demands libraries' and provide evidence of what their contribution really is.

\section{New library models?}

At the same time as education has been undergoing radical change, the literature of librarianship, both in South Africa and internationally, shows that it also has been re-examining its mission in the light of changed political and economic contexts. In one of the basic texts of the field, in 199| Durrance pointed out that the public library is 'a creature of the $19^{\text {th }}$ century' (1991: 279). She identified four areas in need of more in-depth research within public librarianship if it is to meet the needs of the $2 I^{\text {st }}$ century: access to information, information needs, library funding and the public library's role in education. Evidence of shifts in thinking is the recurring call for more relevant public library models for developing societies. Issak's survey (2000) of the position of public libraries in Africa summarises the arguments for a model of public librarianship that contributes to the developmental needs of a community. She argues that Africa has inherited a model of public librarianship that does not reflect its own realities (2000: 12-13). Public library use has decreased in post-colonial African countries. Is it, it is asked, because of a perceived lack of relevance by potential users? Sturges and Neill (1998) also propose a re-examination of library models in Africa. They suggest that the demographics of African countries might encourage public libraries to prioritise the needs of youth. This might imply a shift towards playing a more active role in formal education rather than the traditionally indirect supportive role of the Western model.

The argument here is that African countries do not have well-developed school library systems. Less than $30 \%$ of South African schools for example have functional libraries (Department of Education, 1999). Given the widespread educational reform alluded to above, it is argued that public libraries might have to accept the reality of the non-existence of school libraries and step into a directly educational role.

The role of public libraries in education was a recurring theme in the South African library literature throughout the 1980s. However, much of the writing in the 1980s viewed the heavy use of the public library by school pupils as a 'problem' (for example Van der Walt, 198I; Brooke-Norris, 1986; Niven, 1987), probably because curriculum work falls outside the traditional mission statements of public librarianship. However, there is increasing evidence, summarised by Stilwell and Bell (2003), that the primary need of young South Africans in relation to libraries is for curricular materials.

Once the educational role of the public library is acknowledged in the context of a shortage of school libraries, the combined school library/community library is often put forward as an 'alternative and achievable' model (Le Roux, 200I: 4). The exploration of the model of combined public library/school library in South Africa perhaps began with the NEPI report on libraries in South Africa in the early 1990s (National Education Policy Investigation, 1992) and then was returned to at a conference in Durban hosted by Jenny Karlsson of the Natal Education Policy Unit in 1996 (Karlsson, 1996). The conference included papers on the barriers in the way of establishing sophisticated school library systems in South Africa and others on joint-use libraries in other parts of the world such as Sweden, the US and Australia. The continued influence of Karlsson was clear on the completion of the draft National Policy Framework for School Library Standards circulated by the Department of Education in 1998. The premise of the document is that South Africa cannot afford to provide each school with a library and a librarian. It argues that nonetheless C2005 is a resource-based curriculum, requiring access to learning and information resources. Its solution to this conundrum is a progressive range of different models of school library service - ranging from classroom box libraries to the 'one-school-one-library'. One of its models is the joint use public library/school library which refers to a public library that might serve a number of schools in its immediate community. The influence of Jenny Karlsson and the Natal Education Policy Unit continued in 1997 with the Library Practice for Young Learners project - another outcome of the conference in Durban (Wettmark, 2002). The project, sponsored by BIS, a Swedish Library Association, and SIDA, the Swedish Agency for International Development Cooperation, drew together key officials and practitioners across all provinces. Its first aim was to develop the professional capacity of school library staff in Sweden and South Africa. A subsequent aim was to test the models provided in the National Policy Framework for School Library Standards document. Three case studies of pilot sites were published (Naiker \& Mbokaza, 2002), one of which reports on the Makhuva Information Centre, a resource centre set up 
in a garage by a few community volunteers to serve the community as well as a number of schools. The case of Makhuva illustrates the problems caused by barriers between government departments but also how these barriers can be overcome once people from the various sectors recognise the need to collaborate.

The growing recognition of the need for collaboration across sectors was shown in the initiative of the Pretoria Office of UNESCO, the National Committee for Library Co-Operation, which established a task team in the late 1990s to examine the identified need for better cooperation between the public library sector and the school library sector. The preface to its report states that 'collaboration between school and public library systems would seem for everybody the way forwards, particularly in rural areas, where availability of books is limited and trained librarians are scarce' (National Committee for Library Co-Operation, 2000: 5). The report gives a stamp of approval to the same range of joint use library models provided in the draft National Policy Framework for School Library Standards. In her Masters thesis completed in 200I, the editor of the UNESCO report, Sophia Le Roux, suggests some possible guidelines for South Africa for joint use libraries (200I).

The impact of these initiatives towards new models of library service, outlined above, has so far been limited. They perhaps too hastily nailed their colours to the National Policy Framework. This document, though completed in 1997 after widespread consulting, was apparently rejected by the Department of Education in 2002. The process of school library policy making has since been stalled. Karlsson, herself a leader in these projects as shown above, recently commented that the Library Practice for Young Learners project perhaps distracted key role-players to the detriment of the crucial national policy-making process (2003: 6).

\section{Public libraries in South Africa: 'Victims' of C2005?}

As the above projects and reports have unfolded, the position of school libraries in South Africa has remained precarious - as evidenced in several papers at the national conference Ghost Libraries and Curriculum 2005 in July 2002 (Education Library Information and Technology Services, 2002).

The lack of school libraries has put pressure on public libraries. Public librarians at national conferences have responded to the situation by calling for funds from provincial education departments to alleviate the pressures of increased school learner numbers (for example Hendrikz, 1998; Leach, 1998). Lor (1998: II), head of South Africa's National Library, contended in 1998 that budget cut-backs were crippling libraries. My own study of 67 children's librarians in Cape Town in 1999 found evidence of how these pressures were contributing to low morale (Hart, 2000a). There was consensus among the respondents that $\mathrm{C} 2005$ has indeed brought increased pressures at the same time as they are experiencing shrinking staff and materials budgets. A constant refrain was: 'We are doing the work of school librarians'. My conclusion at the time was that children's and youth librarians in Cape Town's public libraries were feeling victimised by the new curriculum.

Maepa and Mhinga's research project within a community library in Limpopo Province paints a similar picture of library staff struggling to meet the needs of school learners (2003: 270). They analyse the barriers that hinder effective use of the library by teachers and learners in the $\mathbf{2 8}$ schools in the region, of which only one has a library. These include a lack of insight among principals and educators into the educational role of a library - perhaps, the authors speculate, because they themselves have had little experience of a library in their own education. One result is learners' coming to the library with ill-defined and inappropriate project topics. Librarians have to confront these taxing topics - usually with no prior consultation with teachers.

Maepa and Mhinga perhaps provide an answer to the conundrum mentioned above. It is true that Curriculum 2005 is on paper a library friendly system. It expects learners to use a wide range of resources in the course of independent research projects. It therefore should have enhanced the position of the library profession whose libraries provide the sites for this kind of learning. Yet there is consensus among librarians that the position of libraries - school and public has deteriorated in the last few years. How can this puzzling contradiction be explained? Could it be that educators and curriculum planners just do not share librarians' understanding of what a resource-based curriculum means? The literature of educational change includes a thread on the significance of teachers' beliefs and on, what Barnes calls, their 'frames' (1992). Similarly, the literature of information literacy education, at school and tertiary level, highlights the importance of teachers' perceptions of information and its use in learning. As Brown points out:

To ask teachers to change the materials they use for teaching, and the teaching approaches they use, is to require a change in their basic beliefs about how students learn (1988: 13).

Both Maepa and Mphinga (2003) and Karlsson (2003) make the point that only a small proportion of South African teachers and curriculum planners will have had access to libraries in their own education. Just because the prevailing ethos is 'progressive', librarians cannot assume that they will gain a better footing in education. In |98| Morrill wrote a paper that might hold some useful lessons in which he demonstrates the ambivalence of many so-called progressive 
movements in American education towards libraries. Two South African PhD theses completed in 1993 were based on the premise that educational change would lead to calls for more and better school libraries (Fredericks, 1993; Job 1993). However, Fredericks' findings suggest that educators in the early 1990s lacked insight into the potential role of libraries in educational transformation in South Africa.

\section{Evidence based advocacy: a change agent strategy}

The above discussion of the impact (or non-impact) of Curriculum 2005 on public and school libraries suggests that South African libraries have not fared well in the new educational dispensation. It has two implications for librarians who might want to move away from victim to agent status. Firstly, the profession has to engage more vigorously with educationists spelling out what a library contributes to a resource-based curriculum. This engagement needs to apply the insights within the literature of educational change that point to the importance to change of the deeply held convictions of educators about learning and libraries. The second implication is they will need to provide evidence of their present role in the curriculum and use this to convince educationists.

In recent years, the concept of 'evidence-based advocacy' has taken root in the thinking of school librarianship internationally. There is recognition that years of advocacy have not succeeded in improving the position of libraries. The Australian academic, Ross Todd, challenges librarians to be less passive and to document their work more rigorously by means of small-scale research projects $(200 \mathrm{I})$. He, himself, has partnered school librarians in action research in order to provide evidence of their importance to the learning programme.

Todd works within the sphere of school librarianship, but there have been similar calls within public librarianship. Durrance (|99|: 284) warns that, without continuous research in the needs of their customers, public librarians might be accused of relying on outdated and limiting assumption. She identifies a gap between researchers and practitioners. Public librarians perceive research to be esoteric and irrelevant, and so do not read it. And researchers, she claims, do not consult enough with practitioners. Both Todd and Durrance would agree that anecdotal evidence is not enough in a climate of accountability and reduced public spending.

\section{A study of school learners' use of two Cape Town public libraries}

As an example of the kind of research Todd talks of, at the end of 2002 I decided to undertake a small study in two public libraries in the community of Vista (a pseudonym for the purposes of research) that were hosting some University of Western Cape students. The University of the Western Cape's involvement in Vista came out of the Joint Education Trust's CHESP initiative, which had identified it as an appropriate site for its pilot service learning programme. The programme began with an orientation session in July 2002 that introduced the students to the Vista communities. A panel of youth workers, health workers, police, and social workers discussed the social issues facing the youth of the area including high rates of teenage pregnancy, HIV/AIDS, gangsterism, abuse, unemployment and poverty.

Preliminary discussions with library staff uncovered much criticism of the local teachers. Typical complaints were: teachers do not come to the library; they do not inform the library of school projects in good time; and learners are not being taught how to use the library effectively. The Vista libraries' staff told me that none of the schools in Vista has a functioning library and frequently pointed out in early interviews that they were 'doing the work of school librarians'.

Research problem and methodology

This phrase became the focus of the research study that I undertook with the help of the UWC students. As mentioned earlier, the claim 'public libraries are doing the work of school libraries' had cropped up in my study of children's librarians in 1999 (Hart, 2000a) and had been echoed at gatherings of public librarians (for example at the Public and Community Library Interest Group's session at the LIASA conference in 2002).

The study of the use of two public libraries by school learners that I describe in this paper forms just one part of a larger case study of the schools of Vista, which will document how the schools within Vista are managing the project and portfolio work of C2005. However, the study of the two libraries' school users can stand alone. The purpose here is not to give a systematic account of the data gathered and its analysis - but rather to highlight the aspects relevant to the themes of this paper.

Vista lends itself to the research problem as it has two medium-sized public libraries (Vista Library and Vista East), each of which serves a manageable number of schools within reach - that is about four or five in the catchment area of each. Both libraries belong to the same metropolitan sub-structure and to that sub-structure's network of libraries. The facilities in both the Vista libraries are similar to other township libraries in Cape Town as documented in a study in 1999 (Hart, 2000a). One difference between the two is that Vista Library is a pilot site for the SmartCape Internet project, which means that it has a bank of PCs with Internet access. 
The investigation over four days of the use of the two public libraries by school learners set out to throw light on the question of how much the Vista libraries are filling the assumed gap caused by the non-existence of school libraries. Some of the questions it asks are:

- How many learners from the surrounding schools are coming to the two libraries?

- Why do learners come to the public libraries?

- Which learners from which schools are using the local library? And for what?

- What other sources of information \& resources do the learners use?

- Are there differences in the patterns of use between the two libraries?

More complex questions lie behind these. For example:

- What do the learners need from the library?

- How are learners' needs for information literacy education being met?

- Does the public library have the required capacity to take on the active educational role that is being suggested in various quarters?

These last questions might well be answered only after the larger case study of the schools is complete.

Over the period of four afternoons, Monday to Thursday, in the last week of October 2002, 894 interviews with school learners coming into the two libraries were conducted. The interview used a structured questionnaire, comprising 16 questions gathering data on learners' backgrounds, their reasons for coming to the library that day, and their broader information-seeking behaviour. It had been piloted in another library close to the University, which was also hosting UWC students. After the first day, a second, shorter, questionnaire was used for any learner who reported at once that he or she had already been interviewed. These 89 questionnaires are not included in the analysis given in this paper. The UWC students were instructed to try to interview every school learner coming into the library - excepting those not wishing to take part. It is estimated that about $80 \%$ of the learners in the libraries that week were included. The data were then entered on an Excel spreadsheet for summary and statistical analysis (where useful).

Other data were gathered by means of interviews and observation over several weeks. I conducted preliminary interviews with the managers of the two libraries - using a questionnaire evolved in an earlier study of libraries in Cape Town in 1999 (Hart, 2000a). These formal interviews were followed up with frequent more informal conversations with them and with the other library staff members.

Findings

The major finding is the high numbers of learners using the libraries. Over the four days a total of 799 usable questionnaires were completed as well as 89 'second round' questionnaires. Library staff assured us that these numbers are not unusual in the course of the school term, and the experience of the UWC students over a number of weeks confirms this. My photographs document the problems these high numbers bring, especially for the older, smaller Vista Library. Vista East Library is only two years old and was built to cope with the large study spaces required by disadvantaged township learners, who often do not have conditions at home conducive to study. Every chair at Vista Library is occupied in the afternoons. Large queues form at the single photocopier and large crowds of children congregate around the bank of SmartCape PCs. Both libraries adhere to a policy that ejects school learners at 5.00pm every afternoon. This means that use by school learners is telescoped into a few short hours. Observations record that both libraries are rather quiet in the mornings.

It is probable that many of the respondents will not be formally registered members, as membership requires parents' signatures. Witbooi (200I), in her study of the membership of a library in a nearby suburb, suggests that high levels of adult illiteracy, together with perceptions that the library is for the educated middle class, mean that many children in a disadvantaged community are not signed up library members.

There are significant differences in the age groups, grades, and the language groups using the two libraries. These will not be discussed here as they do not pertain to the focus of this paper.

Analysis of the completed questionnaires shows how important a role the public libraries are playing in the school life of the learners. The use involves more than one-off visits. Many report that in the course of their school projects they return to the library frequently - with 76 learners claiming to have made seven visits or more for their current project. The mean number of visits is 2.15. (see Table 2). 
Table 2 Number of visits to library to do this project?

\begin{tabular}{ll}
\hline No. of Visits & Respondents \\
\hline 1 & 561 \\
2 & 61 \\
3 & 52 \\
4 & 20 \\
5 & 16 \\
6 & 13 \\
7 or more & 76 \\
\hline Total & 799 \\
\hline & \\
Median No $=$ & 1 \\
Mean No $=$ & 2.15 \\
Maximum $=$ & 14 \\
\hline
\end{tabular}

Another finding that points to the crucial role of the libraries is that very few learners use any other library. Of the 799 respondents, 623 - that is $78 \%$ - said that they never use any other library. Twenty-seven (3\%) said they also use a school library; 16 use the Bellville Library - the large district library some kilometres away that is designed to serve the reference needs of the municipal sub-structure that Vista is part of. Others named various public libraries throughout Cape Town, probably those close to their schools (see below).

Table 3 shows that the figure on use of school libraries is ambiguous, as in a later question 234 respondents (29\%) said that in the past year they had used 'books in their school library' for their school work. One respondent in Vista Library gave a clue towards a possible explanation for the contradiction when he said that he used some 'old books' from the library at school but it was not a 'real' library. Of the 234 claiming to use books in the school library, 156 (66\%) are Vista respondents - whose schools can be labelled as ex-House of Representative (HOR) schools. Many of them have the remnants of the school libraries that were established in the 1980s but that, since the amalgamation of school systems in the mid 1990s, have been neglected (Hart, 2000b; Le Roux, 200I: 160).

Table 3 Sources of information used this year for schoolwork

\begin{tabular}{ll}
\hline Source & Respondents \\
\hline Books at school provided by teachers & 480 \\
Books in school library & 234 \\
Books at home belonging to family & 221 \\
Personal contacts & 113 \\
Internet at the library & 85 \\
Internet at school & 64 \\
Internet at home & 46 \\
NGOs & 24 \\
Internet at Icafe & 2 \\
\hline
\end{tabular}

The list of schools from where the respondents come makes interesting reading. At the start of the study, the librarians in each library had reported that they served four or five schools. Yet the reality is that their school users come from $7 \mathrm{I}$ different schools scattered throughout the neighbouring areas. A later question, which asked about use of other libraries, revealed that these children might well also be using the library close to their school. It is clear, however, that many of the children who travel out of their home communities to attend school choose to do their homework in the library close to home. Despite the range of $7 \mathrm{I}$ schools, the study shows that two or three schools dominate the use of each of the libraries.

The question that probed why the learners were in the library that day is the heart of the study. Originally, II categories were allowed for, but these were extended to 16 on analysis of the open-ended question that encouraged 
respondents to give 'other' reasons that might not be spelled out. The table that follows lists the responses. On average most respondents come in for more than one reason - to do a project and to photocopy, for example.

Table 4 Why did you come to the library today?

\begin{tabular}{llll}
\hline Reason & Vista Library & Vista East Library & Total \\
\hline Work on school project / portfolio & 193 & 134 & 327 \\
Sit in library to do homework & 80 & 176 & 256 \\
Use library for assignment & 64 & 135 & 199 \\
Bring back / take out book & 91 & 106 & 197 \\
Photocopying & 63 & 94 & 157 \\
Sit and read & 43 & 84 & 127 \\
Meet / be with friends & 57 & 67 & 124 \\
Read info on hobby / interest & 8 & 42 & 50 \\
Pass time & 27 & 20 & 47 \\
Use computers & 31 & 7 & 38 \\
Personal information & 7 & 15 & 22 \\
Study for Exam & 0 & 19 & 19 \\
Admin & 7 & 6 & 13 \\
Help Others & 1 & 7 & 8 \\
Games & 4 & 2 & 6 \\
Use Phones & 0 & 2 & 2 \\
\hline & 483 & 782 & 1265 \\
\hline Mean no. of reasons per respondent & 1.2 & 2.1 & 1.6 \\
\hline
\end{tabular}

Analysis of the total for both libraries together shows that the most common reason is to work on a project; the second is to sit in the library to do homework; the third is to use library materials to complete an assignment; the fourth is to bring back or borrow a book. The role of the library in the social life of young people is rather striking. Rather a high proportion of the visits involve meeting friends and passing the time.

The respondents seem to use the libraries very little for their personal information needs. Vista youth face huge social problems and, if it is indeed true that the local schools do not have libraries, the question has to be asked where the young people of Vista find information on HIV/AIDS, sex education, violence, crime, careers, and, so on. Millward (I994), in describing her work in a public library in Johannesburg in 1994, highlights the important contribution public libraries can make to the life-skills of young South Africans. This is an issue that requires follow-up inside the Vista schools.

The data about use of computers by Vista learners have to be viewed against the backdrop of the large national and provincial projects to bring computers to school learners. The goal of these projects is to fast-track historically disadvantaged learners into the global information society. Two questions in the questionnaire focused on the use of computers. One asked whether the respondent was in the library to use a computer and another later question asked whether they ever used the Internet - at school, home or in the library - as an information source. Only 38 respondents over the four days said that they had come to the library that day 'to use the computers' - this is about $5 \%$ of the 800 respondents over the four days. At first this low figure is puzzling, as observation and photographs record that the SmartCape computers are in constant use by scores of young people. However, a closer look at the photos reveals that the users of the PCs are young men - not school learners. With the roll-out of the SmartCape project to all other libraries in Cape Town in the next year, this is clearly an issue for public library staff. The fact that only 52 respondents - that is just over $6 \%$ - reported that they sometimes use the Internet at their schools for information points to an important role for the SmartCape project. The study in Vista Library might also point to another issue - the role of gender in the use of the PCs. Girls are nowhere to be seen in the photographs of the SmartCape computers at Vista Library.

Some conclusions of the Vista study

Any generalised statement of conclusions has to be cautious. As mentioned above, the study of the learners' use of the Vista libraries is the first part of a case study of the schools in Vista. The high response rate means that the study gives a valid picture of the case study site. Moreover, I believe that it might give a fairly typical picture of South African libraries, at least of those in the rapidly growing townships on the edges of our cities. Supporters of case study methodology contend that the knowledge gained from the study of a single site can, under certain conditions, be more valuable than 
large-scale surveys (Stake, 1994). Thus Delamont and Hamilton, in their book on single classroom research, claim that 'through the detailed study of one particular context it is still possible to clarify relationships, pinpoint critical processes and identify common phenomena' (1984: 19).

The major finding of the Vista study is the heavy use of the libraries by school learners, which is not reflected in the issue and membership statistics of either library. It is clear that the learners rely on the public library for their school learning.

The study of the Vista Libraries so far documents quantity of use - it does not however examine quality of use. For example, it does not follow up whether the information needs of the learners are in fact being met or whether the experience in the public library is developing the information literacy of the learners. Photographs document the long queues of children at Vista Library's photocopying machine. The study does not investigate what happens once the page from the book is copied. Observation and staff interviews indicate that school learners get little support or guidance inside the libraries. The large numbers flocking into the libraries in the afternoons make any sustained individual guidance difficult. Staff place books deemed relevant for the current projects on the school project shelves and children help themselves. No education in the use of indexes for example was observed. Indeed, there is no catalogue or database or subject index available for public use anyway. The only scaffolding provided is the Dewey signage on the shelves. In reply to a question on retrieval facilities, one of the librarians in charge made the comment: 'We have to take them [learners] to the shelves' (Interview 12 September). Given the high numbers in the afternoons, it is difficult to see how children can learn independent information retrieval skills, especially as no retrieval tools are available.

The questionnaire gathered information about project topics and about the educators behind them, which will be useful in the next phase of the case study. Given the library staff's rather negative perceptions of educators, mentioned above, it is interesting that $52 \%$ of respondents said that their teacher had told them to use the library. In the preliminary interviews, both sets of library staff recognised the need for more sustained contact with the schools in the vicinity. They had made sporadic attempts to work more closely with local schools. They claimed, for example, that they had tried to get teachers to communicate their assignments and projects but that most teachers soon forgot to do this. The Vista East staff were especially critical of the high school just across the road - saying that its educators had nothing to do with the library. Yet that school forms the largest user group for the library.

Despite these comments, it is clear that the Vista libraries are playing a vital role in the learning programme of their young users. They are a crucial source of materials for school projects and for homework assignments.

\section{Victims to agents? Some suggestions from the Vista study}

The study of the Vista libraries, hopefully, has demonstrated how a small-scale study might provide evidence in support of public libraries.

It has shown that the staff at the Vista libraries might well claim to be doing the work of school libraries. They are providing for the curricular information needs of their users - even if it is by default. The proviso 'by default' is due to the doubt over whether they are in fact meeting the learning needs of their users with regard to independent research and information literacy skills. To do this they will have to plan more systematic and structured educational programmes perhaps using the relatively quiet mornings. Research in good practice in information literacy education identifies the following characteristics:

- a process approach using frameworks such as Carole Kuhlthau's ISP model (1993)

- systematic programming - in which skills are taught sequentially and audited

- prior identification of learning outcomes and follow-up assessment

- a tailored approach - designing interventions to meet the needs of the specific learner group

- a 'just in time' approach in which skills are taught as needed - in the course of a project, for example, not always at the beginning of the academic year.

Neither of the Vista libraries is engaged in this kind of programming. Perhaps it will be possible only if libraries focus on a few schools and on key grades in these schools.

To move into this kind of active leadership role will require some re-thinking within public library circles. Librarians will need to learn to talk the same language as educationists; they will need to become experts on Curriculum 2005; they will need to design effective learning programmes.

Above all, they will need to be convinced themselves that information literacy education belongs in their mission statements. Witbooi comments that, at present, there is a gap between the reality on the ground and library policy statements. Her study of library membership in the Kuils River community in Cape Town finds school learners to be the biggest group of library patrons. Yet the official policy documents do not reflect this educational role - leading her to speculate that local authorities might not be aware of the contribution of public libraries to formal education (Witbooi, 200I: 97). 
For public libraries to establish and sustain these programmes will require explicit endorsement of their formal educational role by their own governance structures and the educational authorities such as the Western Cape Education Department. This endorsement will give the credibility needed to establish partnerships with local educators. As long as public libraries perform their educational role in ad hoc improvised ways, with no formal recognition of their work, they will remain victims.

This paper has argued that educational change has brought an enhanced role for public libraries in South Africa. If the opportunity is taken up, then the attention will surely shift from how the curriculum has impacted on libraries towards how libraries are impacting on the curriculum.

\section{References}

Asselin, M M. 200I. Factors of effective school libraries: a survey of perspectives of teachers, teacher-librarians, and principals. In Hughes, P. \& Selby, I. Eds. Inspiring connections: learning, libraries \& literacy: proceedings of the Fifth International Forum on Research in School Librarianship. Seattle: IASL: I-I7.

Barnes, D. 1992. The significance of teachers' frames for teaching. In Russell, T \& Munby, H. Teachers and teaching: from classroom to reflection. London: Falmer Press: 9-31.

Breivik, P S and Senn, J A. 1998. Information literacy: educating children for the $21^{\text {st }}$ century. 2nd ed. Washington, DC: National Education Association.

Brooke-Norris, S B. 1986. The Johannesburg Reference Library and the crisis in black education. South African journal of library and information science, 54 (4): 200-202.

Brown, J. 1988. Changing teaching practice to meet current expectations. Emergency librarian, 16(2): 9-14.

Capra, F. 2003. The hidden connections : a science for sustainable living . London: Flamingo.

Delamont, S \& Hamilton, D. 1984. Revising classroom research: a continuing cautionary tale. In Delamont, S. Ed. Readings on interaction in the classroom. London: Methuen: 3-28.

Department of Education. 1998. A National policy framework for school library standards. Discussion document. Pretoria: Department of Education. Unpublished report.

Department of Education. 1999. South African school library survey 1999. National report. Pretoria: Department of Education and Human Sciences Research Council.

Department of Education. 2000. A South African curriculum for the twenty-first century. Report of the Review Committee on

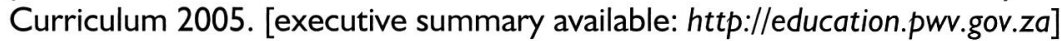

Department of Education. 2002. Revised national curriculum statement. June 2002. available: http://education.pwv.gov.za/

Diepraam, F, Bester, M. 1993. Onderwysstelseldeterminante wat die funksioneering van die media-onderwyser beinvloed. Suid-Afrikaanse tydskrif vir biblioteek-en inligtingkunde, 6I(3): I3I-I37.

Durrance, J C. 199I. Research needs in public librarianship. In McClure, C R \& Hernon, P. Library and information science research: perspectives and strategies for improvement. Norwood, NJ: Ablex: 279-295.

Education Library Information and Technology Services. 2002. Ghost Libraries and Curriculum 2005: [proceedings of] Ist Annual Provincial Conference, I I- / 3 July. Durban: ELITS, Department of Education and Culture KwaZulu Natal.

Ekhaml, L. 200I. The use of PBL in a library course via online distance learning. Journal of educational media and library sciences, 38(3): $24 I-9$.

Fredericks, G. 1993. Educational developments and the role of the school library and teacher-librarian in the education of Blacks in South Africa with special reference to a sample of schools in the Cape Peninsula. DPhil thesis, University of the Western Cape.

Fullan, M G. 1991. The new meaning of educational change. $2^{\text {nd }}$ ed. London: Cassell.

Hart, G. 2000a. Cape Town's children's librarians. Cinderella's of the library world? Cape Librarian, 44 (4): $72-74$.

Hart, G. 2000b. Project work as a vehicle for information literacy education in a circuit of South African schools. IFLANET. Available online: www.ifla.org.

Hendrikz, F. 1998. Public libraries in South Africa 1998: an overview. Paper presented at the annual conference of the Library \& Information Association of South Africa, November 1998, Bloemfontein. Unpublished paper.

Issak, A. Ed. 2000. Public libraries in Africa: a report and annotated bibliography. Oxford: International Network for the Availability of Scientific Publications.

Job, C. 1993. The influence of change on the role and profession of the media teachers in modern education in South Africa. DPhil thesis, University of South Africa.

Karlsson, J. Ed. 1996. School learners and libraries: proceedings of conference on 28-29 November 1995 held at the Tropicana Hotel, Durban, KwaZulu-Natal, South Africa. Dalbridge: Education Policy Unit, University of Natal.

Karlsson, J. 2003. The politics of making a new space for school libraries in South Africa. In Zinn,S, Hart G, \& Howe, E. Eds. IASL reports 2003: school libraries breaking down barriers. Selected papers from the 32nd Annual Conference of the International Association of School Librarianship and the 7th International Forum on Research in School Librarianship, Durban, South Africa, 7-II July 2003. Seattle: IASL: I-9.

Kuhlthau, C C. 1993. Seeking meaning: a process approach to library and information services. Westport, Conn: Ablex.

Le Roux, S. 200I. School-community libraries: some guidelines for a possible model for South Africa. MLIS thesis, University of Pretoria.

Leach, A. 1998. An overview of the public library sector in South Africa post 1994. Innovation, 16,3-19.

Library and Information Association of South Africa. School Libraries \& Youth Services Interest Group. 2000. The need for school libraries in the South African curriculum: a response from LIASA to a South African Curriculum for the Twenty First Century Report of the Review Committee on Curriculum 2005. Unpublished paper, 
Lombo, S. 2002. The relationship between OBE, learner support materials and a school library. In Education Library Information and Technology Services. Ghost Libraries and Curriculum 2005: [proceedings of] Ist Annual Provincial Conference, I I- I 3 July. Durban: ELITS, Department of Education and Culture KwaZulu Natal: 3-6.

Lor, PJ. 1998. Memorandum on the state of libraries in South Africa, March 1998. LIASA Newsletter, 2(I): 7-I2.

Maepa, E. \& Mhinga, R. 2003. Integrating a community library into the teaching and learning programme of local schools: experiences from Seshego Community Library, South Africa. In Zinn,S, Hart G, \& Howe, E. Eds. IASL reports 2003: school libraries breaking down barriers. Selected papers from the 32nd Annual Conference of the International Association of School Librarianship and the 7th International Forum on Research in School Librarianship, Durban, South Africa, 7-II July 2003. Seattle: IASL: 270-279.

Marsh, C. \& Morris, P. 1991. Curriculum development in East Asia. London: Falmer Press.

Millward, J. 1994. Young adult library services in Johannesburg: addressing the needs of teenagers in a multi-cultural society in transition. International review of children's literature and librarianship, 9 (2): 57-72.

Morrill, R L. 198I. The school library and progressive educators: two points of view. School library media quarterly, 9(3): 145$15 \mid$.

Naiker, S. \& Mbokazi, S. 2002. Developing libraries for South African learners and teachers: three case studies. Durban: Education Policy Unit (Natal).

National Committee for Library Co-Operation. 2000. National guidelines for co-operation between community and school libraries. Pretoria: UNESCO Pretoria Office.

National Education Policy Investigation. 1992. Library and information services: report of the NEPI Library and Information Services Research Group. Cape Town: OUP/NECC.

Niven, M. 1987. The problem of the provision of facilities and materials for school projects. Artes Natales, 5(10): 26-32.

Stadler, C. 1991. Competing visions for school libraries in South Africa. Innovation, 3: 15-23.

Stake, R E. 1994. Case studies. In Denzin, N K \& Lincoln, Y S. Handbook of qualitative research. Thousand Oaks, Calif: SAGE: 236-247.

Stilwell, C. \& Bell, F. 2003. Information needs of learners at Emzamweni High School, Inadi, South Africa: a preliminary report on an assessment linked to the CHESP community based learning model. In Zinn,S, Hart G, \& Howe, E. Eds. IASL reports 2003: school libraries breaking down barriers. Selected papers from the 32nd Annual Conference of the International Association of School Librarianship and the 7th International Forum on Research in School Librarianship, Durban, South Africa, 7-II July 2003. Seattle: IASL: 332-343.

Sturges, P \& Neill, R. 1998. The quiet struggle: information and libraries for the people of Africa. $2^{\text {nd }}$ ed. London: Mansell.

Taylor, N \& Vinjevold, P. 1999. Getting learning right: report of the President's Education Initiative Research Project. Wits: Joint Education Trust.

Todd, R. 200I. Transitions for preferred futures of school libraries: knowledge space, not information space, connections not collections, evidence, not advocacy. Keynote paper. $30^{\text {th }}$ Annual Conference of the International Association of School Librarianship, Auckland, New Zealand 9-12 July 200I. available www.iasl-s/o.org/virtualpaper200 I

Van der Walt, P J. 1981. Reference services to children and students in the public library. Libri Natales, 12 (3): 3-9.

Wettmark, L. 2002. To set the ball rolling. Library Project for Young Learners (LPYL) : a Swedish-South African School Library project 1997-2002. Karlstad: Bibliotek I Samhälle (BIS).

Witbooi, S. 200I. The educational role of the public library: Kuils River as case study. MBibl thesis, University of the Western Cape.

Zinn, S. 2002. Information literacy skills: a national perspective. In Education Library Information and Technology Services. Ghost Libraries and Curriculum 2005: [proceedings of] Ist Annual Provincial Conference, II- 13 July. Durban: ELITS, Department of Education and Culture KwaZulu Natal: 6-13. 